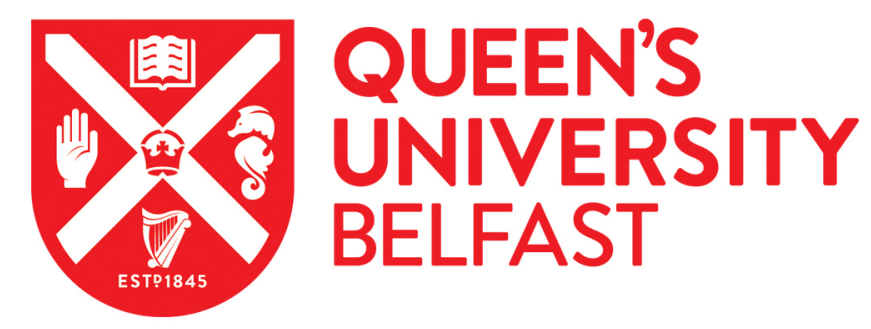

\title{
Silica-supported chlorometallate(III) ionic liquids as recyclable catalysts for Diels-Alder reaction under solventless conditions
}

Matuszek, K., Chrobok, A., Latos, P., Markiton, M., Szymanska, K., Jarzebski, A., \& Swadzba-Kwasny, M. (2016). Silica-supported chlorometallate(III) ionic liquids as recyclable catalysts for Diels-Alder reaction under solventless conditions. CATAL YSIS SCIENCE \& TECHNOLOGY, 6(22), 8129-8137. https://doi.org/10.1039/C6CY01771A

Published in:

CATALYSIS SCIENCE \& TECHNOLOGY

Document Version:

Peer reviewed version

Queen's University Belfast - Research Portal:

Link to publication record in Queen's University Belfast Research Portal

Publisher rights

(C) The Royal Society of Chemistry 2016

This work is made available online in accordance with the publisher's policies. Please refer to any applicable terms of use of the publisher.

\section{General rights}

Copyright for the publications made accessible via the Queen's University Belfast Research Portal is retained by the author(s) and / or other copyright owners and it is a condition of accessing these publications that users recognise and abide by the legal requirements associated with these rights.

Take down policy

The Research Portal is Queen's institutional repository that provides access to Queen's research output. Every effort has been made to ensure that content in the Research Portal does not infringe any person's rights, or applicable UK laws. If you discover content in the Research Portal that you believe breaches copyright or violates any law, please contact openaccess@qub.ac.uk. 


\title{
Silica-supported chlorometallate(III) ionic liquids as recyclable catalysts for Diels-Alder reaction under solventless conditions
}

\author{
Karolina Matuszek, ${ }^{a}$ Anna Chrobok, ${ }^{a *}$ Piotr Latos, ${ }^{a}$ Magdalena Markiton, ${ }^{a}$ Katarzyna Szymańska, ${ }^{\mathrm{b}}$ \\ Andrzej Jarzębski, ${ }^{b, c}$ Małgorzata Swadźba-Kwaśny ${ }^{d}$

\begin{abstract}
A range of Lewis acidic metal chlorides were tested as homogenous catalysts in a model Diels-Alder reaction; $\mathrm{AlCl}_{3}$ and $\mathrm{GaCl}_{3}$ performed best in terms of conversion and endo:exo selectivity. Based on this outcome, corresponding chlorometallate(III) ionic liquids were tested as homogenous catalysts, without decrease in perfomrance compared to the chlorides. Finally, these ionic liquids were heterogenised by covalent tethering of the cation onto a multimodal porous silica support; such supported chlorogallate(III) ionic liquids are reported for the first time. Supported chlorometallate(III) ionic liquids were used as recyclable, heterogeneous catalysts for Diels-Alder reaction under solventless conditions. High yields ( $99 \%$ and and high endoselectivities $(95 \%)$ were obtained after very short reaction times $(5 \mathrm{~min})$, at near-ambient temperature $\left(25^{\circ} \mathrm{C}\right)$.
\end{abstract}

\section{Introduction}

The Diels-Alder reaction is a powerful transformation, allowing for the construction of six-membered carbocycles (Scheme 1).

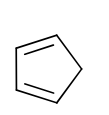

CPD<smiles>C=CC(=O)OC</smiles>

MA

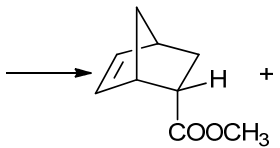

endo

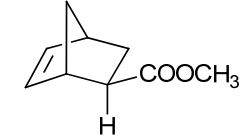

exo
Scheme 1. Diels-Alder cycloaddition of cyclopentadiene to methyl acrylate

The Diels-Alder reaction is the key step in the syntheses of pharmacologically active ingredients, agrochemicals, flavors and fragrances. ${ }^{1}$ Although it can proceed without a catalyst, enhanced reaction rates and selectivities were reported when a catalyst was used. ${ }^{2}$ Lewis acidic catalysts coordinate to the dienophile, influencing both the reaction rate and the selectivity to endo:exo or ortho/para isomers (Scheme 1). ${ }^{3}$ Zinc(II) chloride, boron(III) fluoride, tin(IV) chloride, aluminium(III) chloride, etc. have all been used as catalysts. A range of ionic liquids have also

a. Department of Chemical Organic Technology and Petrochemistry, Silesian University of Technology, Krzywoustego 4, 44-100 Gliwice, Poland, e-mail: Anna.Chrobok@polsl.pl

b. Department of Chemical and Process Engineering, Silesian University of Technology, Strzody 7, 44-100 Gliwice, Poland

. Institute of Chemical Engineering, Polish Academy of Sciences, Battycka 5, 44-100 Gliwice, Poland

d. QUILL, The Queen's University of Belfast, Belfast, BT9 5AG, United Kingdom, email:m.swadzba.kwasny@qub.ac.uk

+ Footnotes relating to the title and/or authors should appear here.

Electronic Supplementary Information (ESI) available: [experimental details, NMR data]. See DOI: 10.1039/x0xx00000x been tested as catalysts for Diels-Alder reaction; ${ }^{4}$ the most active were Lewis acidic chloroaluminate(III) systems. ${ }^{5,6,7}$

Chlorometallate ionic liquids are synthesised by the reaction of a metal halide with an organic halide salt, at various molar ratios, typically reported as molar ratio of the metal halide component, $\chi_{\mathrm{MCl}}$. When metal halide is used in excess $\left(\chi_{\mathrm{MCl}}>\right.$ 0.50 ), oligonuclear, Lewis acidic anions are formed. ${ }^{8}$

An ionic liquid based on 1-ethyl-3-methylimidazolium chloride and a slight excess of aluminium chloride(III), $\left[\mathrm{C}_{2}\right.$ mim $] \mathrm{Cl}-\mathrm{AlCl}_{3} ; \chi_{\mathrm{AlCl} 3}=0.51$ was used as both solvent and catalyst for cycloaddition of cyclopentadiene to methyl acrylate. The reaction rate was 10 times higher than in water, which is one of the most effective solvents for this reaction, and a good endo:exo ratio was obtained (95:5). However, the chloroaluminate(III) ionic liquid was used in a large excess. ${ }^{5}$ In addition, chloroindate(III) ${ }^{9}$ chlorozincate(II) and chlorostannate(II) ionic liquids were found to be active catalyst for the Diels-Alder reaction. ${ }^{10,11}$ There are still some challenges to achieve, like application of catalytic amounts of ionic liquids and lowering reaction times.

Heterogenisation of catalysts can offer advantages in handling, separation and recycling. ${ }^{12}$ By supporting ionic liquids, the required amount of ionic phase can be significantly reduced. In addition, it enables the use of fixed-bed reactor systems. ${ }^{11}$ Three main methods of immobilisation of ionic liquid on silica support: via anion, via cation and physically supported liquid phase (SILP) were described. Hölderich ${ }^{13}$ postulated that for chloroaluminate(III) ionic liquids, immobilisation via cation is the most efficient. Leaching of the active phase is limited compared to the SILP approach due to covalent binding, and the Lewis acidic anion retains its full activity.

Supported chlorometallate ionic liquids, such as chloroaluminates(III), ${ }^{13}$ chloroindates(III), ${ }^{14}$ chloroferrates(III) and chlorostannates $\left(\right.$ II) ${ }^{15}$ were extensively studied as catalysts in Friedel-Crafts alkylation and acylation. In all cases, high 
efficiency, good stability and the possibility of recycling were demonstrated. The performance of SILPs was typically better, and sometimes on par with that of free ionic liquids. Surprisingly, there is only a single report on the application of chlorometallate SILPs for the Diels-Alder. Lewis acidic chloroaluminate(III) ionic, synthesised from poly(4vinylpyridine) or poly(1-vinylimidazole) polymers, exhibited similar activity and selectivity to the homogeneous analogue. ${ }^{16}$ The reaction was carried out in toluene and the selectivity endo:exo product was 61:39. The polymer-supported chloroaluminate(III) catalysts was recycled five times, with a $20 \%$ loss of initial activity.

In this work, we explored the catalytic potential of chlorogallate(III) and chloroaluminate(III) ionic liquids supported on silica by covalently bound cations, under solventless conditions.

\section{Experimental}

\section{Materials and methods}

All reactants were purchased from Sigma-Aldrich and used as received, unless otherwise stated. Dichloromethane was distilled from $\mathrm{P}_{2} \mathrm{O}_{5}$ and stored over activated $3 \AA$ molecular sieves. All metal chlorides were anhydrous, 99.99\% purity, packed in ampules under inert gas. MH-type silica material and 1-methyl-3(triethoxysilylpropyl)imidazolium chloride were prepared according to the literature.

Synthesis of 1-methyl-3-(triethoxysilyl-propyl)imidazolium chloride, [tespmim] Cl

The mixture of $0.12 \mathrm{~mol}$ (3-chloropropyl)triethoxysilane and $0.12 \mathrm{~mol}$ of 1-methylimidazole (freshly distilled) was refluxed at $78^{\circ} \mathrm{C}$ for $24 \mathrm{~h}$ under nitrogen atmosphere. The reaction mixture was cooled down and any remaining volatile substances were removed by rotary evaporation. The crude product was additionally washed with $\mathrm{Et}_{2} \mathrm{O}(5 \times 5 \mathrm{ml})$ and dried under vacuum. The product (slightly yellow viscous oil) was obtained with $98 \%$ yield.

1H NMR (600 MHz, CDCl3, TMS): $d=10.66(\mathrm{~s}, 1 \mathrm{H}), 7.36(\mathrm{~m}, 1 \mathrm{H})$, $7.59(\mathrm{~m}, 1 \mathrm{H}), 4.34(\mathrm{t}, 2 \mathrm{H}, \mathrm{J}=7.40 \mathrm{~Hz}), 4.14(\mathrm{~s}, 3 \mathrm{H}), 3.82(4,6 \mathrm{H}, \mathrm{J}$ $=7.40 \mathrm{~Hz}), 2.05(\mathrm{~m}, 2 \mathrm{H}), 1.20(\mathrm{t}, 9 \mathrm{H}, \mathrm{J}=7.80 \mathrm{~Hz}), 0.61(\mathrm{~m}, 2 \mathrm{H})$; 13C NMR (300 MHz, CDCl3, TMS): $d=138.13,123.34,121.58$, 58.53, 51.66, 36.51, 24.32, 18.2, 7.03. Anal. Calcd.: C, 48.45; H, 8.39; N, 8.69. Found: C, 48.34; H, 8.30; N, 8.77.

General procedure for synthesis of silica support (MH) with the extensive system of meso- and macropores

The synthesis of support using porogenes of different sizes (polyethylene glycol and cetyltrimethylammonium bromide), together with the induction and freezing of the transition structures originating from the phase separation process, led to the formation of a macroporous, interconnected, open network with bimodal system of macropores of micrometer size. In a typical procedure $8.7 \mathrm{~g}$ of polyethylene glycol (PEG) with molecular weight of $35.000 \mathrm{~g} / \mathrm{mol}$ was dissolvedin $100 \mathrm{ml}$ of $1 \mathrm{M}$ $\mathrm{HNO}_{3}$ Sol was stirred until a clear solution was obtained. Then
$83 \mathrm{ml}$ tetraethoxysilane was added slowly and after that $3.84 \mathrm{~g}$ of cetylotrimethylammonium bromide. This solution was left to gel at $40^{\circ} \mathrm{C}$ and aged for 10 days at the same temperature Next the white alcogels obtained were impregnated in a $1 \mathrm{M} \mathrm{NH}_{4} \mathrm{OH}$ solution for $9 \mathrm{~h}$ at $90^{\circ} \mathrm{C}$, washed with deionised water, dried for 4 days at room temperature and then calcined at $550{ }^{\circ} \mathrm{C}$ for $8 \mathrm{~h}$ under air (heating ramp $0.5 \mathrm{~K} / \mathrm{min}$ ). The size and shape of the monoliths were determined by the size and shape of the vessel used. Composition led to the formation of a macroporous, interconnected, open network with bimodal system of macropores of micrometer size. Apart from the macropores, the material also exhibited textural mesopores, with BET surface area of $300 \mathrm{~m}^{2} / \mathrm{g}$, total pore volume $-3.5-4 \mathrm{~cm}^{3} / \mathrm{g}$ and mean mesopore diameter of about $20 \mathrm{~nm}$ (determined by nitrogen adsorption), macropore diameter 30-50 $\mu \mathrm{m}$. The SEM picture of silica support $\mathrm{MH}$ is presented in ESI.

\section{Synthesis of 1-methyl-3-(triethoxysilyl-propyl)imidazolium} chlorometallate(III) ionic liquids, [tespmim] $\left[\mathrm{MnCl}_{(3 n+1)}\right]$

All chlorometallate ionic were prepared according to the general procedure, at a $1 \mathrm{~g}$ scale. ${ }^{17}$ Appropriate amounts of dry [tespmim] $\mathrm{Cl}$ were placed in a round bottom flask equipped with a stirring bar. Then metal chloride $\mathrm{MCl}_{3}$ (where $\mathrm{M}=\mathrm{Al}$ or $\mathrm{Ga}$ ) was added slowly, with stirring to achieve the desired composition, and then allowed to fully react $(1000 \mathrm{rpm}, 3 \mathrm{~h}, 60$ $\left.{ }^{\circ} \mathrm{C}\right)$. All reactions were carried out under dry inert gas. Exact amounts of reactants are listed in Table 1.

\section{Synthesis of 1-methyl-3-(triethoxysilyl-propyl)imidazolium} chlorometallate(III) ionic liquids anchored on the silica support, $\mathrm{MH}$-[tespmim] $\left[\mathrm{M}_{\mathrm{n}} \mathrm{Cl}_{(3 \mathrm{n}+1)}\right]$

$\mathrm{MH}(1 \mathrm{~g})$ was suspended in dry toluene $\left(5 \mathrm{~cm}^{3}\right)$. Next, $1.55 \mathrm{mmol}$ of ionic liquid: [tespmim] $\left[\mathrm{Al}_{2} \mathrm{Cl}_{7}\right]$ or [tespmim] $\left[\mathrm{Ga}_{3} \mathrm{Cl}_{10}\right]$, was added. Two-necked round-bottomed flask was equipped with a nitrogen-filled balloon, closed with a septum and stirred at 80 ${ }^{\circ} \mathrm{C}$ for $3 \mathrm{~h}$. Subsequently, toluene was removed under vacuum and the catalyst was dried for $4 \mathrm{~h}$ at $80{ }^{\circ} \mathrm{C}$ under reduced pressure. To verify ionic liquids immobilisation efficiency ICP, solid state ${ }^{1} \mathrm{H},{ }^{13} \mathrm{C},{ }^{29} \mathrm{Si}$ and ${ }^{27} \mathrm{Al}$ NMR were performed.

Table 1. The amounts of reactants used for the synthesis of chlorometallate ionic liquids

\begin{tabular}{|c|c|c|c|}
\hline $\begin{array}{c}\text { Chlorometallate } \\
\text { ionic liquid }\end{array}$ & $\chi_{\mathrm{MCl}^{a}}{ }^{a}$ & $\begin{array}{l}\text { [tespmim]Cl, } \\
\text { mmol }\end{array}$ & $\begin{array}{l}\mathrm{MCl}_{3}, \\
\mathrm{mmol}\end{array}$ \\
\hline [tespmim] $\left[\mathrm{AlCl}_{4}\right]$ & 0.50 & 2.19 & 2.19 \\
\hline [tespmim] $\left[\mathrm{Al}_{2} \mathrm{Cl}_{7}\right]$ & 0.67 & 1.70 & 3.39 \\
\hline [tespmim] $\left[\mathrm{GaCl}_{4}\right]$ & 0.50 & 2.00 & 2.00 \\
\hline [tespmim $]\left[\mathrm{Ga}_{2} \mathrm{Cl}_{7}\right]$ & 0.67 & 1.48 & 2.96 \\
\hline [tespmim] $\left[\mathrm{Ga}_{3} \mathrm{Cl}_{10}\right]$ & 0.75 & 1.17 & 3.52 \\
\hline
\end{tabular}




\section{Diels-Alder reaction catalysed with homogenous catalysts}

The dienophile $(4 \mathrm{mmol})$ and the catalyst, containing $5 \mathrm{~mol} \%$ of $\mathrm{MCl}_{3}$ per dienophile were placed in a two-necked roundbottomed flask equipped with septum, the balloon with argon and stirring bar. Then the diene $(6 \mathrm{mmol})$ was added dropwise to the vigorously stirred $(1500 \mathrm{rpm})$ reaction mixture. The reaction was carried out at room temperature for 5-120 min, and monitored by gas chromatography.

\section{The Diels-Alder reaction catalysed with supported ionic liquids}

The dienophile $(4 \mathrm{mmol})$ and the catalyst, containing $5 \mathrm{~mol} \%$ of $\mathrm{MCl}_{3}$ per dienophile $\left(0.1235 \mathrm{~g}\right.$ of $\mathrm{MH}$-[tespmim] $\left[\mathrm{Al}_{2} \mathrm{Cl}_{7}\right]$ or $0.0998 \mathrm{~g}$ of $\mathrm{MH}$-[tespmim] $\left[\mathrm{Ga}_{3} \mathrm{Cl}_{10}\right]$ ), were placed in a twonecked round-bottomed flask equipped with septum, the balloon with argon and stirring bar. Then the diene $(6 \mathrm{mmol})$ was added dropwise to the vigorously stirred (1500 rpm) reaction mixture. The reaction was carried out at room temperature for 5-120 $\mathrm{min}$, and monitored by gas chromatography. Afterwards, $1 \mathrm{ml}$ of dichloromethane was added to the mixture, and the catalyst was filtered off. The solvent was removed, and the products were purified by column chromatography (100\% chloroform) or crystallisation, as necessary. All Diels-Alder adducts were characterised by NMR spectroscopy and ESI-MS.

\section{Recycling of $\mathrm{MH}-[$ tespmim $]\left[\mathrm{Ga}_{3} \mathrm{Cl}_{10}\right]$}

For the recycling experiment, amounts of reactants were doubled: dienophile $(8 \mathrm{mmol})$, diene $(12 \mathrm{mmol})$, and $0.1996 \mathrm{~g}$ of $\mathrm{MH}$-[tespmim] $\left[\mathrm{Ga}_{3} \mathrm{Cl}_{10}\right]$. After the reaction, the product and unreacted starting materials were separated by distillation. Next, the catalyst was dried $\left(4 \mathrm{~h}\right.$ in $80{ }^{\circ} \mathrm{C}$ under reduced pressure) and reused.

\section{Analyses}

Gas chromatography was performed using a Perkin Elmer Clarus 500 gas chromatograph equipped with an $\mathrm{SPB}^{\mathrm{TM}}-5$ column (30 $\mathrm{m} \times 0.2 \mathrm{~mm} \times 0.2 \mu \mathrm{m}$ ) with $n$-decane as internal standard.

GC-MS was performed using an Agilent gas chromatograph 7890C (HP-5 MS capillary column, $30 \mathrm{~m} \times 0.25 \mathrm{~mm} \times 0.25 \mu \mathrm{m}$, conjugated with an Agilent mass spectrometer $5975 \mathrm{C}$ with $\mathrm{EI}$ ionization $(70 \mathrm{eV})$. Products were identified using the NIST/EPA/NIH Mass Spectral Library.

The morphology of silica support was determined with scanning electron microscopy (SEM) using a Philips XL30 apparatus.

${ }^{29} \mathrm{Si}$ MAS NMR spectra were measured at $59.517 \mathrm{MHz}$ using a Bruker HP-WB high-speed MAS probe equipped with a $4 \mathrm{~mm}$ zirconia rotor to record the NMR spectra at a spinning speed of $8 \mathrm{kHz}$. Solid state ${ }^{13} \mathrm{C}$ NMR experiments were performed using a Bruker $500 \mathrm{MHz}$ NMR spectrometer. For ${ }^{27} \mathrm{Al} \mathrm{NMR}$ solid state measurements a Bruker Avance III $400 \mathrm{MHz}$ WB spectrometer using $4 \mathrm{~mm}$ probe MAS was used (calibration with $\mathrm{Al}_{2} \mathrm{O}_{3}$ as external standard).

Inductively coupled plasma (ICP) measurements were performed on Optical Emission Spectrometer ICP-OES Varian 710-ES.

\section{Results and discussion}

\section{Homogenous Diels-Alder reaction catalysed with metal chlorides}

Although Lewis acidic metal chlorides are the most common catalysts for the Diels-Alder reaction, ${ }^{2}$ the literature lacks comparative studies of the activity different metal chlorides, which could guide the selection of best chlorometallate ionic liquids. In the preliminary screening, a range of metal chlorides $\left(\mathrm{AlCl}_{3}, \mathrm{GaCl}_{3}, \mathrm{InCl}_{3}, \mathrm{FeCl}_{3}, \mathrm{SnCl}_{4}, \mathrm{SnCl}_{2}, \mathrm{TiCl}_{4}\right.$ ) were tested as Lewis acidic catalysts in a model cycloaddition of methyl acrylate (MA) to cyclopentadiene (CPD), shown in Scheme 1. The influence of the catalyst on conversion and selectivity is shown in Figure 1.

Aluminium(III) chloride and gallium(III) chloride performed best, with high conversion and high endo-selectivity (94\%), achieved after only 5 minutes. Reaction catalysed with tin(IV) chloride also proceeded at a very high rate, but the endoselectivity was lower (91\%). Conversely, catalysis with iron(III) chloride led to good endo-stereoselectivity (94\%), but with lower conversion of dienophile $\left(\alpha_{\mathrm{MA}}=65 \%\right)$, caused by competitive polymerisation of cyclopentadiene. Other metal chlorides $\left(\mathrm{TiCl}_{3}, \mathrm{InCl}_{3}\right.$ and $\left.\mathrm{SnCl}_{2}\right)$ performed poorer, both in terms of conversion and selectivity. Consequently, chlorometallate ionic liquids based on $\mathrm{AlCl}_{3}$ and $\mathrm{GaCl}_{3}$ were selected for further study.

\section{Homogenous Diels-Alder reaction catalysed with chlorometallate(III) ionic liquids}

Lewis acidity of chlorometallate ionic liquids depends on both metal electrophilicity and the mole fraction of metal

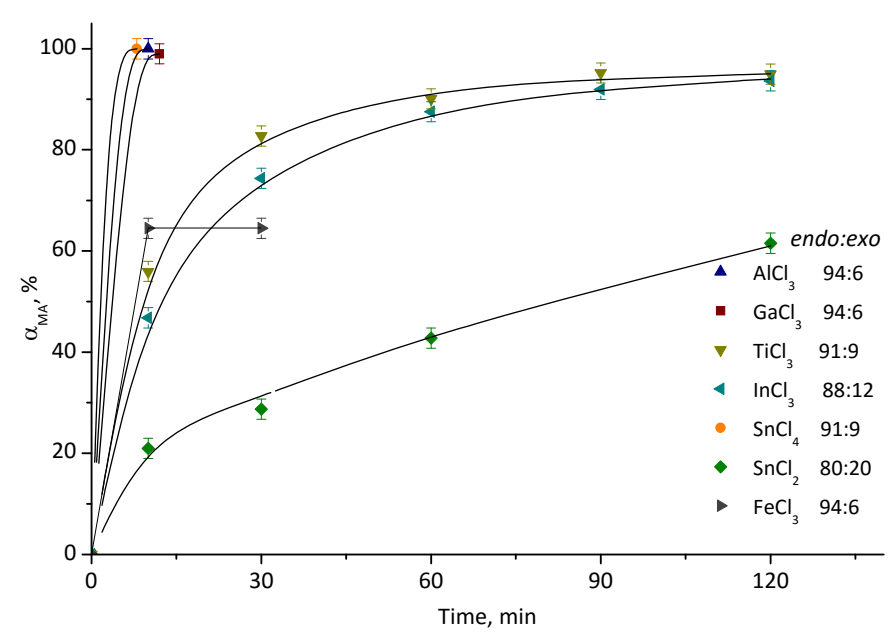

Fig. 1 The influence of the metal chloride catalyst on the conversion of methyl acrylate $\left(\alpha_{\mathrm{MA}}\right)$ and the stereoselectivity in Diels-Alder reaction.

Reaction conditions: $\mathrm{T}=25^{\circ} \mathrm{C} ; \mathrm{r}=1500 \mathrm{rpm}$; CPD (4 mmol); MA (6 mmol); catalyst loading $5 \mathrm{~mol} \%$ per MA. 
chloride, $\chi_{\mathrm{Mcl}}$. For chloroaluminate(III) and chlorogallate(III) systems, compositions of $\chi_{\mathrm{MCl} 3}=0.50$ are neutral (and typically not catalytically active), and $\chi_{\mathrm{MCl} 3}>0.50$ are Lewis acidic. Whereas chloroaluminates(III) form homogenous ionic liquids up to $\chi_{\mathrm{AICl} 3}=0.67,{ }^{18}$ chlorogallate(III) ionic liquids remain homogenous within a wide range of compositions, with $\mathrm{GaCl}_{3}$ contents up to $\chi_{\mathrm{GaCl} 3}=0.75$ reported. ${ }^{19}$

Firstly, chlorometallate(III) ionic liquids were tested as homogenous catalysts. The catalytic activity of metal chlorides and corresponding chlorometallate(III) ionic liquids, in homogenous mode, is compared in Table 2. For meaningful comparison, in all cases there is $5 \mathrm{~mol} \%$ of nominal metal(III) chloride content per dienophile. Two ionic liquids were used: one build of the most popular cation used to form ionic liquids, 1-ethyl-3-methylimidazolium, $\left[\mathrm{C}_{2} \mathrm{mim}\right]^{+}$, and second with silylfunctionalised cation 1-methyl-3-(triethoxysilylpropyl) imidazolium, [tespmim] ${ }^{+}$, which enables covalent tethering on silica support.

As expected, a Lewis-basic ionic liquid, $\left[\mathrm{C}_{2} \mathrm{mim}\right] \mathrm{Cl}$, and neutral chlorometallate systems $\left(\chi_{\mathrm{MCl} 3}=0.50\right)$ do not exhibit catalytic properties. Discrepancy between the activity of chloroaluminate(III) ionic liquids containing different cations, $\left[\mathrm{C}_{2} \mathrm{mim}\right]^{+}$and $[\text {tespmim }]^{+}$, and of same composition $\left(\chi_{\mathrm{AlCl} 3}=\right.$ $0.67)$ are negligible, with high methyl acrylate conversion (99\% after $5 \mathrm{~min}$ ) and high stereoselectivity (endo:exo $=95: 5$ ). Although chlorogallate(III) ionic liquid with $\chi_{\mathrm{GaCl} 3}=0.67 \mathrm{had}$ inferior performance, the system with increased $\mathrm{GaCl}_{3}$ content, $\chi_{\mathrm{GaCl}}=0.75$, performed on par with chloroaluminate(III) systems. This is in agreement with literature report on higher Lewis acidity of the $\chi_{\mathrm{GaCl}}=0.75$ composition, compared to the $\chi_{\mathrm{GaCl} 3}=0.67$ one.

Demonstrably, with both $\mathrm{AlCl}_{3}$ and $\mathrm{GaCl}_{3}$, and the corresponding chlorometallate ionic liquids, it is possible to achieve full methyl acrylate conversions and very high stereoselectivities (endo:exo $=95: 5)$ in short reaction times (5 $\mathrm{min}$ ) and under solventless conditions. This is in stark contrast to the only prior report on the cyclopentadiene cycloaddition to methyl acrylate catalysed with a chloroaluminate(III) ionic liquid, where very long reaction time (72 h) was reported, along with high catalyst loading and the presence use of solvent. ${ }^{4}$

Table 2 Chlorometallate(III) ionic liquids as catalyst in Diels-Alder reaction

\begin{tabular}{|c|c|c|c|c|}
\hline Catalyst & $\chi_{\mathrm{MCl3}}$ & Time, min & $\alpha_{M A}, \%$ & endo:exo \\
\hline$\left[\mathrm{C}_{2} \mathrm{mim}\right] \mathrm{Cl}$ & 0.00 & 10 & 2 & $75: 25$ \\
\hline$\left[\mathrm{C}_{2} \mathrm{mim}\right]\left[\mathrm{AlCl}_{4}\right]$ & 0.50 & 5 & 2 & $75: 25$ \\
\hline$\left[\mathrm{C}_{2} \mathrm{mim}\right]\left[\mathrm{Al}_{2} \mathrm{Cl}_{7}\right]$ & 0.67 & 5 & 99 & $95: 5$ \\
\hline [tespmim][AlCl 4$]$ & 0.50 & 5 & 9 & $75: 25$ \\
\hline [tespmim] $\left[\mathrm{Al}_{2} \mathrm{Cl}_{7}\right]$ & 0.67 & 5 & 99 & $95: 5$ \\
\hline [tespmim] $\left[\mathrm{GaCl}_{4}\right]$ & 0.50 & 5 & 6 & $80: 20$ \\
\hline [tespmim] $\left[\mathrm{Ga}_{2} \mathrm{Cl}_{7}\right]$ & 0.67 & 5 & 73 & $95: 5$ \\
\hline [tespmim] $\left[\mathrm{Ga}_{3} \mathrm{Cl}_{10}\right]$ & 0.75 & 5 & 98 & $95: 5$ \\
\hline
\end{tabular}

Reaction conditions: $\mathrm{T}=25^{\circ} \mathrm{C} ; \mathrm{r}=1500 \mathrm{rpm}$; CPD (4 mmol); MA (6 mmol); catalyst contains $5 \mathrm{~mol} \%$ of $\mathrm{MCl}_{3}$ per MA

\section{Preparation of the heterogeneous catalyst, $\mathrm{MH}-$ [tespmim] $\left[\mathrm{M}_{\mathrm{n}} \mathrm{Cl}_{(3 \mathrm{n}+1)}\right]$}

Compared to extensively studied chloroaluminate(III) ionic liquids, chlorogallate(III) systems offer equal or even slightly higher Lewis acidity ${ }^{17}$ and superior moisture stability. ${ }^{20}$ Despite some reports on their superior performance, ${ }^{7,21,22}$ applications of chlorogallate(III) systems in Lewis acid catalysis are relatively poorly explored - arguably due to their much higher price compared to the chloroaluminate(III) counterparts. Immobilisation and recycling could aid to overcome the cost issue; surprisingly, there were no literature reports on the immobilisation of chlorogallate ionic liquids. Therefore, it was considered valuable to carry out a comparative study of the catalytic performance of both chloroaluminate(III) and chlorogallate(III) systems, immobilised on a silica support.

Multimodal porous silica ( $\mathrm{MH}$ ) was chosen as a support. ${ }^{23,24}$ Materials with a multimodal hierarchical pore structure, containing micro-, meso- and macropores, benefit from decreased limitations to mass transport to and from the active sites due to their unique structure. Interconnected macropores are the main transport arteries to the smaller micro/mesopores, which in turn are responsible for the activity and selectivity of a chemical reaction. ${ }^{25} \mathrm{MH}$-type silica materials have been successfully used in our group as carriers for various catalysts, including lipase ${ }^{26}$ and Brønsted acidic ionic liquids, ${ }^{27}$ which led us to select them also for this work. The material prepared for this work contained macropores, as well as textural mesopores, with BET surface area of $300 \mathrm{~m}^{2} / \mathrm{g}$, total pore volume $-3.5-4 \mathrm{~cm}^{3} / \mathrm{g}$ and mean pore mesopore diameter of about $20 \mathrm{~nm}$ (determined by nitrogen adsorption), macropore diameter $30-50 \mu \mathrm{m}$. (ESI). ${ }^{25,26}$

Immobilisation of chlorometallate ionic liquids on silica, reported by Hölderich, ${ }^{15}$ included binding of the cation (in the chloride salt form) on silica, via triethoxysilyl functionality on the cation, and subsequent addition of aluminium(III) chloride to form chloroaluminate(III) ionic liquids. This, however, could result in some metal chloride being deposited directly on the silica surface, and in its pores. To avoid this unfavorable phenomenon, Yin et al. proposed a modified procedure, whereby a silyl-functionalised cation was firstly reacted with metal chloride, to form a chlorometallate ionic liquid, and the resulting product was bound onto silica. ${ }^{11}$ This synthetic route was used in this work (Scheme 1). In the first step, (3chloropropyl)triethoxysilane was treated with 1methylimidazole to yield 1-methyl-3-(triethoxysilylpropyl) imidazolium chloride, [tespmim] Cl. Then, a metal chloride was added to [tespmim] Cl to form chlorometallate ionic liquids of desired composition: [tespmim] $\left[\mathrm{MnCl}_{(3 n+1)}\right], \chi_{\mathrm{MCl} 3}=0.67$ or 0.75 , where $\mathrm{M}=\mathrm{Al}$ or $\mathrm{Ga}$. Then, the ionic liquids were covalently tethered onto the silica. 


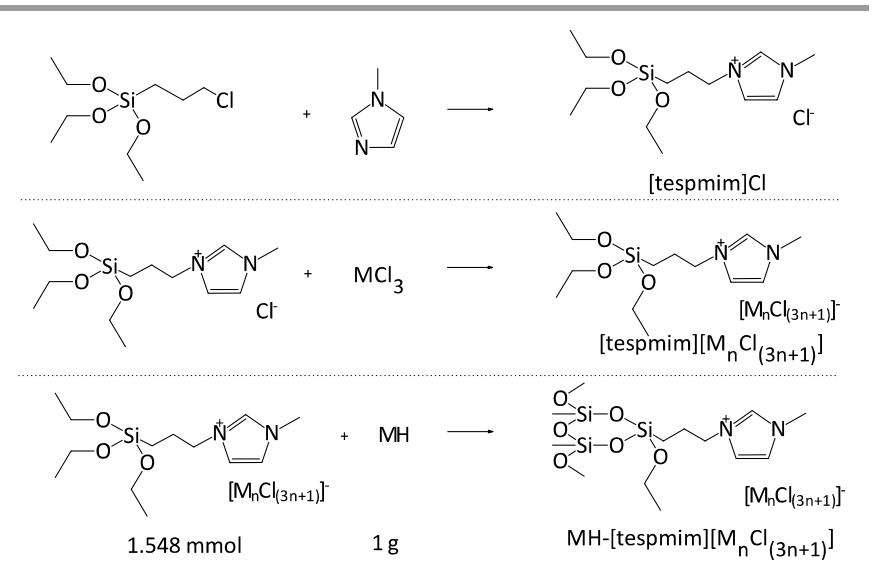

Scheme 1 Immobilisation of chlorometallate ionic liquids onto silica

The atomic absorption (ICP OES) analysis, performed for selected catalysts, have shown high efficiency of the immobilisation method (Table 3). The differences between the measured and calculated amount of the metal content in the catalyst were within the standard error of the method.

\section{Table 3 ICP analysis of catalysts}

\begin{tabular}{ccc} 
Catalyst & $\begin{array}{c}\text { Measured content } \\
\text { of metal in catalyst, } \\
\text { mass \% }\end{array}$ & $\begin{array}{c}\text { Theoretical content } \\
\text { of metal in catalyst, } \\
\text { mass \% }\end{array}$ \\
\hline $\mathrm{MH}$-[tespmim] $\left[\mathrm{Al}_{2} \mathrm{Cl}_{7}\right]$ & 4.52 & 5.24 \\
$\mathrm{MH}-$ & 13.92 & 14.45 \\
\hline tespmim] & $\left.\mathrm{Ga}_{3} \mathrm{Cl}_{10}\right]$ & 0
\end{tabular}

Cross-polarised ${ }^{29} \mathrm{Si}$ MAS-NMR was performed to confirm the covalent binding of the ionic liquid to the silica support. The ${ }^{29} \mathrm{Si}$ CP-MAS NMR spectrum of $\mathrm{MH}$-[tespmim] $\left[\mathrm{Al}_{2} \mathrm{Cl}_{7}\right]$, is shown in Figure 2. The strong signal at $-111 \mathrm{ppm}$ is assigned to the $(\mathrm{SiO})_{3} \mathrm{Si}-\mathrm{OSi}$ group, indicating that the ionic liquid is attached to the silica surface. Peak at $-69 \mathrm{ppm}$ corresponds to the $(\mathrm{Si}-\mathrm{O})_{2^{-}}$ SiR-OEt group (where $R$ is the rest of ionic liquid, Fig. 2).

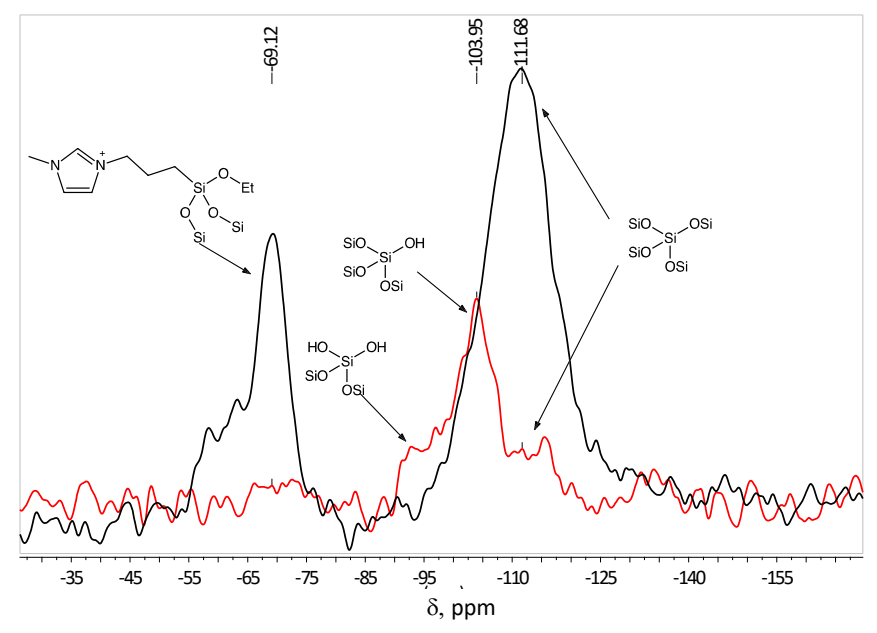

Fig. $2{ }^{29} \mathrm{Si}$ MAS NMR of $\mathrm{MH}$ (red) and $\mathrm{MH}$-[tespmim] $\left[\mathrm{Al}_{2} \mathrm{Cl}_{7}\right]$ (black)
This confirms that the condensation reaction between the surface $\mathrm{Si}-\mathrm{OH}$ groups of the support and $\mathrm{Si}-\mathrm{OEt}$ groups of the ionic liquid cation occurred. The cations are tethered to the surface mainly via two Si-O-Si bonds (larger signal at $-69 \mathrm{ppm}$ ), as opposed to one Si-O-Si bond (weaker signal at -60 ppm).

The corresponding ${ }^{13} \mathrm{C}$ MAS NMR spectrum, despite significant line broadening, features all signals originating from the ionic liquid cation (ESI).

${ }^{27} \mathrm{Al}$ MAS NMR spectrum of $\mathrm{MH}$-[tespmim] $\left[\mathrm{Al}_{2} \mathrm{Cl}_{7}\right]$ (Figure 3) was recorded to confirm the anionic speciation, and to check for the presence of unsupported $\mathrm{AlCl}_{3}$. A single signal at $102 \mathrm{ppm}$ is consistent with ${ }^{27} \mathrm{Al}$ nuclei surrounded by four chlorines. Signal broadening indicates the presence of $\left[\mathrm{Al}_{2} \mathrm{Cl}_{7}\right]^{-}$, rather than more symmetrical $\left[\mathrm{AlCl}_{4}\right]^{-}{ }^{28}$ Signal from free $\mathrm{AlCl}_{3}$, expected at -1.2 ppm, was not observed. ${ }^{15}$

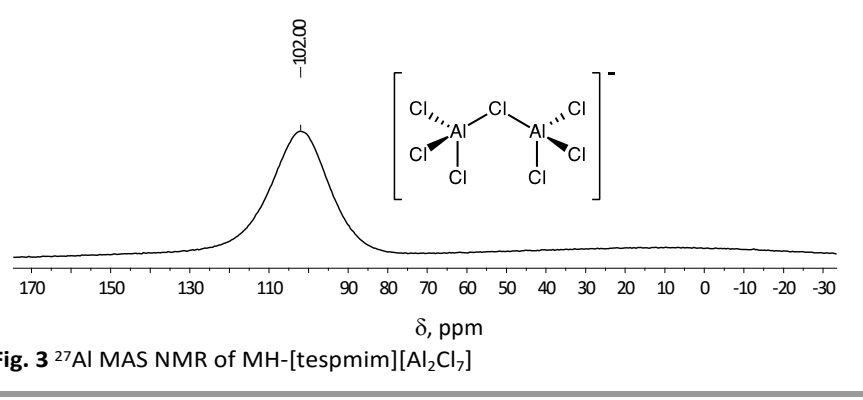

Diels-Alder reaction catalysed with supported chlorometallate(III) ionic liquids, $\mathrm{MH}$-[tespmim] $\left[\mathrm{M}_{\mathrm{n}} \mathrm{Cl}_{(3 \mathrm{n}+1)}\right]$

To harness numerous benefits of heterogenisation of ionic liquid catalysts, ${ }^{12}$ two best-performing systems: [tespmim] $\left[\mathrm{Al}_{2} \mathrm{Cl}_{7}\right]$ and [tespmim] $\left[\mathrm{Ga}_{3} \mathrm{Cl}_{10}\right]$, were immobilised on the support and used as catalysts (Table 4). Both systems had similar performance in terms of conversions and selectivities, on par with that of homogenous systems (viz. Table 2). Isolated yields were also very high. Considering postulated superior moisture stability of chlorogallate(III) ionic liquids, ${ }^{20}$ the $\mathrm{MH}$ [tespmim] $\left[\mathrm{Ga}_{3} \mathrm{Cl}_{10}\right.$ ] was selected for further investigations.

Table 4 Immobilised ionic liquids as catalysts of Diels-Alder reaction

\begin{tabular}{cccc}
\hline Catalyst & $\boldsymbol{\alpha}_{\mathrm{MA}}, \%$ & $\begin{array}{c}\text { Isolated } \\
\text { yield, \% }\end{array}$ & endo:exo \\
\hline $\mathrm{MH}$-[tespmim] $\left[\mathrm{Al}_{2} \mathrm{Cl}_{7}\right]$ & 100 & 97 & $95: 5$ \\
$\mathrm{MH}$-[tespmim] $\left[\mathrm{Ga}_{3} \mathrm{Cl}_{10}\right]$ & 100 & 97 & $95: 5$ \\
\hline
\end{tabular}

Reaction conditions: $\mathrm{T}=25^{\circ} \mathrm{C} ; \mathrm{r}=1500 \mathrm{rpm} ; \mathrm{CPD}(4 \mathrm{mmol}) ; \mathrm{MA}(6 \mathrm{mmol}) ;$ catalyst contains $5 \mathrm{~mol} \%$ of $\mathrm{MCl}_{3}$ per MA $\left(0.1235 \mathrm{~g}\right.$ of $\mathrm{MH}$-[tespmim] $\left[\mathrm{Al}_{2} \mathrm{Cl}_{7}\right] ; 0.0998 \mathrm{~g}$ of $\mathrm{MH}-$ [tespmim] $\left.\left[\mathrm{Ga}_{3} \mathrm{Cl}_{10}\right]\right)$, reaction time $5 \mathrm{~min}$.

The studies on the influence of the catalyst loading on methyl acrylate conversion $\left(\alpha_{\mathrm{MA}}\right)$ and stereoselectivity showed that the nominal loading of $5 \mathrm{~mol} \%$ of $\mathrm{GaCl}_{3}$ per methyl acrylate ( $0.0998 \mathrm{~g}$ of the catalyst) is sufficient to obtain full conversion in 5 min (Figure 4). Decreased quantities of the catalyst resulted in major decrease in methyl acrylate conversion and minor drop in stereoselectivity. 


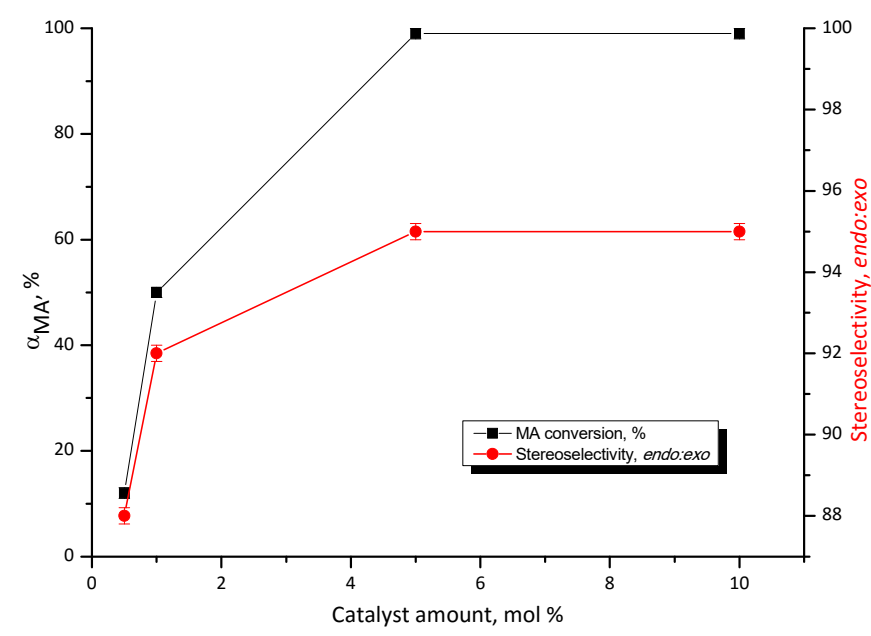

Fig. 4 The influence of catalyst loading on the conversion of methyl acrylate $\left(\alpha_{\mathrm{MA}}\right)$ and the stereoselectivity of Diels-Alder reaction.

Reaction conditions: $\mathrm{T}=25^{\circ} \mathrm{C} ; \mathrm{r}=1500 \mathrm{rpm}$; $\mathrm{CPD}(4 \mathrm{mmol})$; $\mathrm{MA}(6 \mathrm{mmol})$; catalyst $\mathrm{MH}$-[tespmim] $\left[\mathrm{Ga}_{3} \mathrm{Cl}_{10}\right]$ contains from $1-10 \mathrm{~mol} \%$ of $\mathrm{MCl}_{3}$ per $\mathrm{MA}$, reaction time 5 $\min$.

Influence of the reaction temperature on both selectivity and conversion of the cycloaddition is shown in Figure 5. Decreasing the temperature from 22 to $-10{ }^{\circ} \mathrm{C}$ did not affect either conversion or stereoselectivity of the reaction. At $-15^{\circ} \mathrm{C}$, a slight increase in selectivity (96\%) was accompanied by significant decrease in conversion of methyl acrylate $\left(\alpha_{M A}=\right.$ $84 \%)$. Further decrease in temperature to $-94{ }^{\circ} \mathrm{C}$ resulted in further minor increase in selectivity (97\%), but major drop in conversion ( $\left.\alpha_{\mathrm{MA}}=69 \%\right)$. Considering nearly negligible improvements in selectivity, it was established that it is most energy-efficient to maintain the reaction temperature at nearambient $\left(25^{\circ} \mathrm{C}\right)$.

Under these optimised conditions, supported catalysts perform very well compared to other Lewis acids reported in the literature (Table 5). Reaction time was reduced to $5 \mathrm{~min}$, compared to hours in other reports, with conversions higher than in all but one report, and the catalyst loading on the low end of the reported spectrum. Moreover, endo-selectivity was at a very good level of $95 \%$, without the need to cool the reaction below ambient temperature.

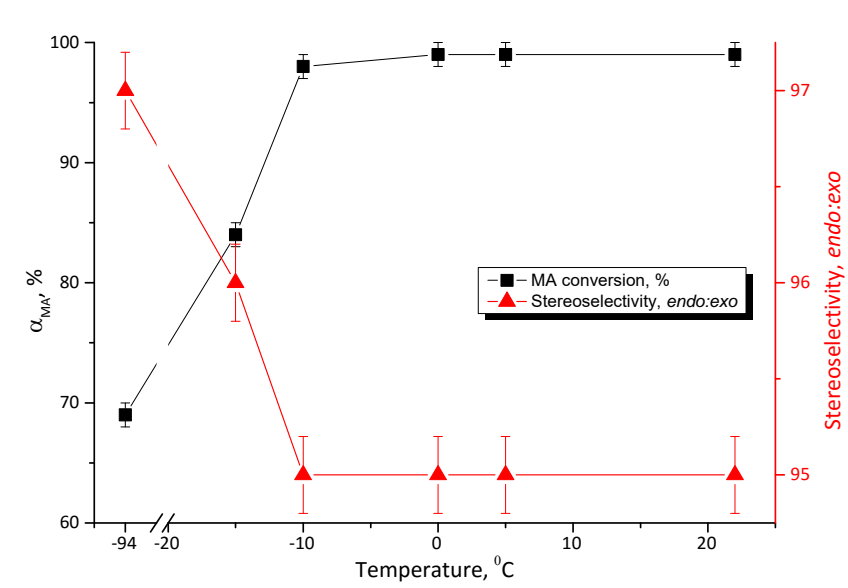

Fig. 5 The influence of temperature on the conversion methyl acrylate $\left(\alpha_{M A}\right)$ and the stereoselectivity of Diels-Alder reaction.

Reaction conditions: $\mathrm{T}=25^{\circ} \mathrm{C} ; \mathrm{r}=1500 \mathrm{rpm}$; CPD (4 mmol); MA (6 mmol); catalyst contains $5 \mathrm{~mol} \%$ of $\mathrm{MCl}_{3}$ per $\mathrm{MA}\left(0.0998 \mathrm{~g}\right.$ of $\mathrm{MH}$-[tespmim] $\left.\left[\mathrm{Ga}_{3} \mathrm{Cl}_{10}\right]\right)$, reaction time 5 $\min$.

Recycling of the immobilised catalyst, $\mathrm{MH}$ [tespmim] $\left[\mathrm{Ga}_{3} \mathrm{Cl}_{10}\right]$ was studied over ten consecutive runs (Figure 6). After each run, the product and unreacted starting materials were distilled off from the catalyst, using Schlenk line to protect it from moisture. Then, the catalyst was charged with fresh starting material, and next catalytic run was commenced. Over four consecutive runs, no changes in conversion and selectivity were observed. After the fourth cycle, the conversion of methyl acrylate started to drop, and selectivity was decreasing from the seventh cycle.

Working under inert conditions, and considering reasonably good moisture stability of chlorogallate(III) systems, deactivation of the catalyst by hydrolysis appears to be unlikely. Since products were removed by distillation, and the ionic liquid was covalently tethered to the support, washing off the catalyst is also improbable.

However, it is known that gallium(III) chloride sublimes easily. It is suspected that, whilst removing the product mixture under reduced pressure, some gallium(III) chloride was removed from the ionic liquid, decreasing the $\chi_{\mathrm{GaCl}}$ value, and consequently the catalytic performance.

Table 5 Comparison of catalysts activity used in the reaction of cyclopentadiene with methyl acrylate

\begin{tabular}{|c|c|c|c|c|c|c|}
\hline Catalyst & Catalyst amount, mol \% & Solvent & $\mathbf{T},{ }^{\circ} \mathrm{C}$ & $t, h$ & $\alpha_{M A}, \%$ & endo:exo \\
\hline $\mathrm{AlCl}_{3}^{29}$ & 10 & DCM & 0 & 4 & 87 & $95: 5$ \\
\hline $\mathrm{Cu}(\mathrm{OTf})_{2}{ }^{29}$ & 10 & DCM & 0 & 4 & 35 & $98: 2$ \\
\hline $\mathrm{ZnI}_{2}^{29}$ & 10 & DCM & $\mathrm{rt}$ & 20 & 16 & $92: 8$ \\
\hline $\mathrm{Ce}(\mathrm{IV})-\mathrm{SiO}_{2}{ }^{30}$ & 20 & - & -20 & 2 & 99 & $98: 2$ \\
\hline $\mathrm{Ul}_{3}(\mathrm{THF})_{4}{ }^{31}$ & 5 & DCM & $\mathrm{rt}$ & 1 & 77 & $95: 5$ \\
\hline $\mathrm{Al}-\mathrm{HMS}^{32}$ & $150 \mathrm{mg} / 1 \mathrm{mmol}$ & hexane & -1 & 18 & 94 & $97: 3$ \\
\hline$\left[\mathrm{C}_{2} \mathrm{mim}\right] \mathrm{Cl}-\mathrm{AlCl}_{3} \chi=0.51^{5}$ & $0.2 \mathrm{ml} / 1 \mathrm{mmol}$ & - & $\mathrm{rt}$ & 72 & 79 & $95: 5$ \\
\hline$\left[\mathrm{C}_{2} \mathrm{mim}\right]\left[\mathrm{Al}_{2} \mathrm{Cl}_{7}\right]$ (this work) & 5 & - & 25 & $5 \mathrm{~min}$ & 99 & $95: 5$ \\
\hline $\mathrm{MH}$-[tespmim] $\left[\mathrm{Al}_{2} \mathrm{Cl}_{7}\right]$ (this work) & 5 & - & 25 & $5 \mathrm{~min}$ & 99 & $95: 5$ \\
\hline
\end{tabular}


Table 6 Diels-Alder reaction of various dienophiles with cyclopentadiene and isoprene in the presence of $\mathrm{MH}$-[tespmim] [Ga3 $\left.\mathrm{Cl}_{10}\right]$ as catalyst.

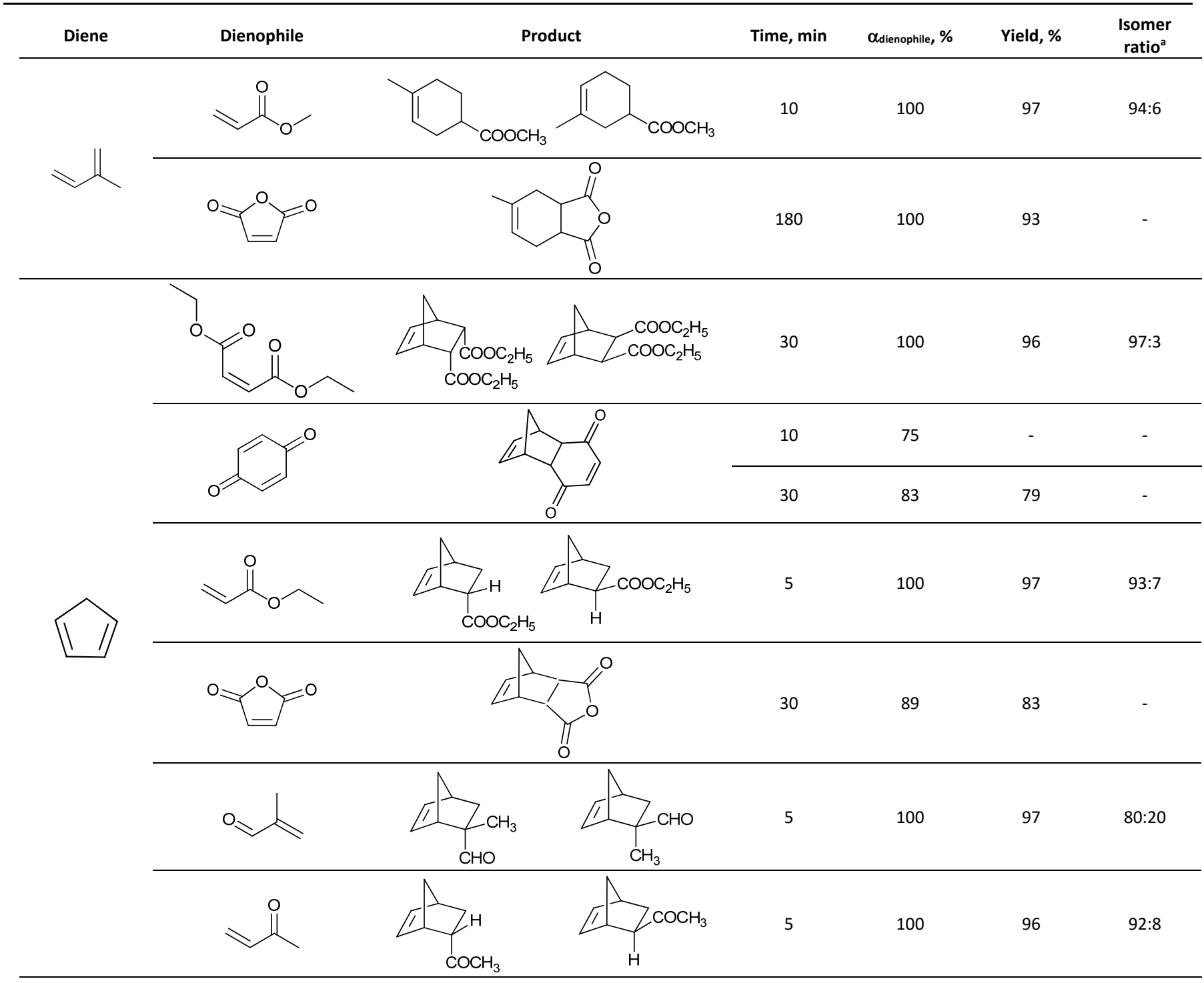

${ }^{a}$ The ratios of 1,4-/1,3-substitiuted isomers or endo:exo isomers. 


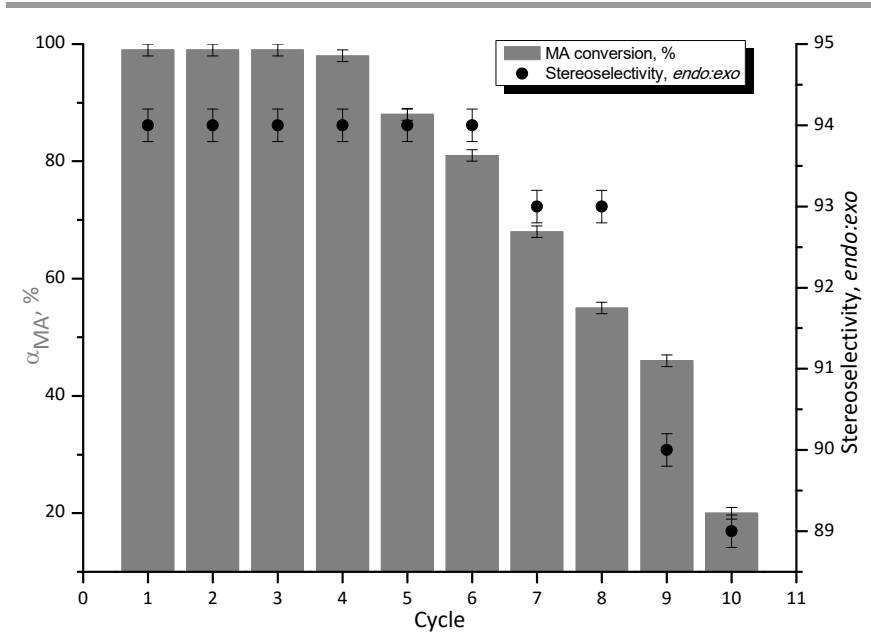

Fig. 6 Recycling of the $\mathrm{MH}$-[tespmim] $\left[\mathrm{Ga}_{3} \mathrm{Cl}_{10}\right]$ catalyst in Diels-Alder reaction.

Reaction conditions: $\mathrm{T}=25^{\circ} \mathrm{C} ; \mathrm{r}=1500 \mathrm{rpm}$; CPD ( $\left.8 \mathrm{mmol}\right)$; MA (12 mmol); catalyst contains $5 \mathrm{~mol} \%$ of $\mathrm{MCl}_{3}$ per $\mathrm{MA}\left(0.1996 \mathrm{~g}\right.$ of $\mathrm{MH}$-[tespmim] $\left[\mathrm{Ga}_{3} \mathrm{Cl}_{10}\right]$ ), reaction time $5 \mathrm{~min}$.

Moving onto the continuous flow system could significantly prolong the life of the catalyst, but such experiments are beyond the scope of this paper.

Finally, in order to test robustness of the new catalytic system, the Diels-Alder reactions with a wide range of dienes and dienophiles were tested, using the $\mathrm{MH}$-[tespmim] $\left[\mathrm{Ga}_{3} \mathrm{Cl}_{10}\right]$ catalyst. Results for two dienes: cyclopentadiene and isoprene, and six dienophiles: ethyl acrylate, diethyl maleate, methacrolein, methyl-vinyl ketone, benzoquinone and maleic anhydride, are shown in Table 5. It was demonstrated that the catalyst was active for all studied reactant combinations, and cycloadducts were formed with high yields and selectivities where applicable), within reaction times typically not exceeding $30 \mathrm{~min}$.

\section{Conclusions}

Lewis acidic metal chlorides were compared as homogenous catalysts in a model Diels-Alder reaction, with $\mathrm{AlCl}_{3}$ and $\mathrm{GaCl}_{3}$ giving highest conversions and endo:exo selectivities. Catalytic performance of the corresponding chlorometallate(III) ionic liquids was on par with metal chlorides.

Chloroaluminate(III) and chlorogallate(III) systems were heterogenised, by covalently binding cations of these ionic liquids onto multimodal porosity silica support. These supported catalysts performed at ambient temperature $\left(25^{\circ} \mathrm{C}\right)$, under solventless conditions, and produced results superior to those reported in the literature. Reaction time was reduced to $5 \mathrm{~min}$, compared to hours in other reports, ${ }^{5}$ with conversions higher than in all but one report, ${ }^{30}$ and low catalyst loading (5\%). Endo-selectivity was at a very good level of $95 \%$, without the need to cool the reaction below ambient temperature.
Supported chlorogallate(III) ionic liquids were demonstrated to be recyclable, and very robust in terms of substrate scope.

\section{Acknowledgements}

This work was financed by National Science Centre of Poland (grant no. UMO-2012/06/M/ST8/00030) and K. Szymańska and A. Jarzębski thanks National Science Center of Poland (grant no. UMO-2013/09/B/ST8/02420). 


\section{Notes and references}

J. A. Funel, S. Abele, Angew. Chem. Int. Ed., 2013, 52, 3822.

F. Fringuelli, A. Taticchi, Diels-Alder reaction. Selected practical methods, John Wiley \& Sons, New York 2002.

3 F. Fringuelli, A. Taticchi, Diels-Alder reaction. Selected practical methods, John Wiley \& Sons, New York, 2002.

4 C. Chiappe, M. Malvaldi and C. S. Pomelli, Green Chem., 2010, 12, 1330.

5 C. W. Lee, Tetrahedron Lett., 1999, 40, 2461.

6 D. M. Bourgeois, G. S. Miracle, P. J. Porter, E. Boros, K. R. Seddon, H. Q. N. Gunaratne, US 20110152566A1, 2011.

7 A. Vidis, E. Kusters, G. Sedelmeier, P. J. Dyson, J. Phys. Org. Chem. 2008, 21, 264.

8 J. Estager, J. D. Holbrey, M. Swadzba-Kwasny, Chem. Soc. Rev., 2014, 43, 847.

9 K. Bica, P. Gärtner, P. J. Gritsch, A. K. Ressmann, C. Schröder, R. Zirbs, Chem. Commun., 2012, 48, 5013.

10 A. P. Abbott, G. Capper, D. L. Davies, R. K. Rasheed, V. Tambyrajah, Green Chem., 2002, 4, 24.

11 D. Yin, C. Li, B. Li, L. Tao, D. Yin, Adv. Synth. Catal., 2005, 347, 137.

12 H. P. Steinrück and P. Wasserscheid, Catal. Lett., 2014, 145, 380.

13 M. H. Valkenberg, C. deCastro, W. F. Hölderich, Green Chem., 2002, 4, 88.

14 H. Z. N. Yu, J. Wang, D. Zhuang, Y. Ding, R. Tan, D. Yin, Microp. Mesop. Mat., 2009, 122, 240.

15 M. H. Valkenberg, C. deCastro, W. F. Hölderich, Appl. Catal., A, 2001, 215, 185.

16 H.W. Bae, J.S. Han, S. Jung, M. Cheong, H.S. Kim, J.S. Lee, Appl. Catal., A, 2007, 331, 34
17 J. Estager, A.A. Oliferenko, K. R. Seddon, M. Swadźba-Kwaśny, Dalton Trans., 2010, 39, 11375

18 H. A. Øye, M. Jagtoyen, T. Oksefjell and J. S. Wilkes, Mater. Sci. Forum, 1991, 73, 183.

19 C. Hardacre, R. W. Murphy, K. R. Seddon, G. Srinivasan and M. Swadźba-Kwaśny, Aust. J. Chem., 2010, 63, 845.

20 S. P. Wicelinski, R. J. Gale, K. M. Pamidimukkala and R. A. Laine, Anal. Chem., 1988, 60, 2228.

21 M. P. Atkins, K. R. Seddon and M. Swadźba-Kwaśny, Pure Appl. Chem., 2011, 83, 1391.

22 M. Markiton, A. Chrobok, K. Matuszek and K. R. Seddon, RSC Adv., 2016, 6, 30460.

23 A. Imhof, D.J. Pine, Nature, 1997, 389, 948.

24 M.E. Davis, Nature, 2002, 417, 813.

25 R. Takahashi, S. Sato, T. Sodesawa, K. Arai, M. Yabuki, J. Catal., 2005, 229, 24.

26 A. Drożdż, A. Chrobok, S. Baj, K. Szymańska, J. Mrowiec-Białoń, A. Jarzębski, Appl. Catal., A, 2013, 467, 163.

27 A. Chrobok, S. Baj, W. Pudło, A. Jarzębski, Appl. Catal., A, 2009, 366, 22.

28 S. Takahashi, M.-L. Saboungi, R. J. Klingler, M. J. Chen and J. W. Rathke, J. Chem. Soc., Faraday Trans., 1993, 89, 3591.

29 C. A. D. Sousa, J. E. Rodríguez-Borges, C. Freire, ISRN Organic Chemistry, 2013, 1.

30 G. M. Ziarani, A. Badiei, A. Miralami, Bull. Korean Chem. Soc., 2008, 29, 47.

31 J. Collin, L. Maria, I. Santos, J. Mol. Catal. A: Chem., 2000, 160, 263.

32 M. Onaka, N. Hashimoto, Y. Kitabata, R. Yamasaki, Appl. Catal., A, 2003, 241, 307. 